\title{
Slime molds as a valuable source of antimicrobial agents
}

\author{
Vida Tafakori*
}

\begin{abstract}
Given the emerging multidrug-resistant pathogens, the number of effective antimicrobial agents to deal with the threat of bacterial and fungal resistance has fallen dramatically. Therefore, the critical solution to deal with the missing effective antibiotics is to research new sources or new synthetic antibiotics. Natural products have different advantages to be considered antimicrobial agents. There are different natural sources for antimicrobial agents, such as bacteria, fungi, algae, slime molds, and plants. This article has focused on antibiotics from slime molds, especially Myxomycetes. The reason why slime molds have been chosen to be studied is their unique bioactive metabolites, especially over the past couple of decades. Some of those metabolites have been demonstrated to possess antibiotic activities. Hence, this article has focused on the potential of these creatures as an alternative source of antibiotics.
\end{abstract}

Keywords: Multidrug, Resistance, Antibiotics, Natural products, Myxomycetes

\section{Introduction}

In 1940, Edward Abraham and Ernest Chain at Oxford University in the United Kingdom affected the Escherichia coli extraction on the penicillin and proved the existence of a penicillinase, which was able to inactivate penicillin, warning about intrinsic antibiotic resistance. This happened soon after the discovery of penicillin in 1928 when the drug was not being used yet (Amenu 2014). Antibiotics, these "wonder drugs," were used to treat injured soldiers and wounded civilians during World War II. However, after penicillin came into clinical use, the additional bacteria developed the ability to resist other antibiotics, unfortunately. Nowadays, the appearance of multidrug-resistant bacteria (Table 1) has made antimicrobial resistance a major threat to global health and development. The emerging multidrug-resistant pathogens have dramatically lowered the number of effective antimicrobial agents to deal with the threat of bacterial and fungal resistance. The provisional leading cause-of-death rankings for 2020 indicate COVID-19 as

*Correspondence: TafakoriV@gmail.com; TafakoriV@Khu.ac.ir Department of Cell and Molecular Biology, Faculty of Science, Kharazmi University, Tehran, Iran the third leading cause of death in the US behind heart disease and cancer (Ahmad et al. 2021). Thus, infectious diseases are still concerned among the most important global social challenge of the world.

Reports estimate that, by 2050, 10 million people will die every year with an estimated economic cost of $\$ 100$ trillion due to antimicrobial resistance unless a global response is mounted to this problem (Simpkin et al. 2017). Accordingly, the critical solution to deal with the missing effective antibiotics is to study on new sources or new synthetic antibiotics.

In the antimicrobial resistance process, microbial cells have developed a complex and redundant barrier to penetration, enzymes to destroy or modify, and pumps to efflux the antibiotic compounds. Hence, between natural products and synthetic ones, the former is preferable since as the microbial cells evolve and gain the ability to develop resistance against antimicrobial agents, natural products also evolve in nature. Another reason is that in the drug discovery sector, synthetic antibiotics are most favor human bioactivity, not suitable for microbial biology (Wright 2014). On the other hand, natural products reflect the true chemical diversity (extensive functional group chemistry and chirality), which does not exist
Springer Open (c) The Author(s) 2021. This article is licensed under a Creative Commons Attribution 4.0 International License, which permits use, sharing, adaptation, distribution and reproduction in any medium or format, as long as you give appropriate credit to the original author(s) and the source, provide a link to the Creative Commons licence, and indicate if changes were made. The images or other third party material in this article are included in the article's Creative Commons licence, unless indicated otherwise in a credit line to the material. If material is not included in the article's Creative Commons licence and your intended use is not permitted by statutory regulation or exceeds the permitted use, you will need to obtain permission directly from the copyright holder. To view a copy of this licence, visit http://creativeco mmons.org/licenses/by/4.0/. 
Table 1 Multidrug resistant bacteria observed in the community (Duin and Paterson 2016)

\begin{tabular}{|c|c|c|}
\hline Multidrug resistant (MDR) phenotype & $\begin{array}{l}\text { Epidemiologic setting of community-onset } \\
\text { infections }\end{array}$ & Major antibiotics resistance mechanisms \\
\hline Methicillin-resistant S. aureus (MRSA) & $\begin{array}{l}\text { Household colonization; farm animal exposure } \\
\text { (emerging) }\end{array}$ & mecA, mecC \\
\hline Vancomycin-resistant Enterococci (VRE) & Typically health care-associated & $\operatorname{van} A, \operatorname{van} B$ \\
\hline $\begin{array}{l}\text { Carbapenem-resistant Acinetobacter baumannii } \\
\text { (CRAB) }\end{array}$ & Extremely rare & Carbapenemases \\
\hline Multi-drug resistant $P$ seudomonas aeruginosa & Extremely rare & $\begin{array}{l}\text { Extended-spectrum beta-lactamases, carbapen- } \\
\text { emases, and efflux systems }\end{array}$ \\
\hline $\begin{array}{l}\text { Extended-spectrum beta-lactamase (ESBL)- } \\
\text { producing Enterobacteriaceae }\end{array}$ & $\begin{array}{l}\text { Endemic in Asia; in low-prevalence areas travel } \\
\text { to Asia }\end{array}$ & $\begin{array}{l}\text { Extended-spectrum beta-lactamases, and efflux } \\
\text { systems }\end{array}$ \\
\hline Carbapenem-resistant Enterobacteriaceae (CRE) & Rare at present; emerging in India and China & Carbapenemases \\
\hline
\end{tabular}

in synthetic products (Phillipson 2007). On the other hand, for some natural products, the apparent lack of industrial interest may be due to the inherent time-consuming working process with natural products, difficulties in access and supply, costs of collection, extraction, and isolation, and standardization limitations of crude drugs (Phillipson 2007; Harvey 2008). However, despite all these problems, their advantages still make natural products the preferable choice for antimicrobial agent sources.

\section{Natural sources of antimicrobial agents}

Although antibiotics generally refer to antibacterials, since the term has not exactly been defined, it encompasses a wide variety of agents, including antibacterial, antifungal, antiviral, and antiparasitic drugs (Cheesbrough 2006).

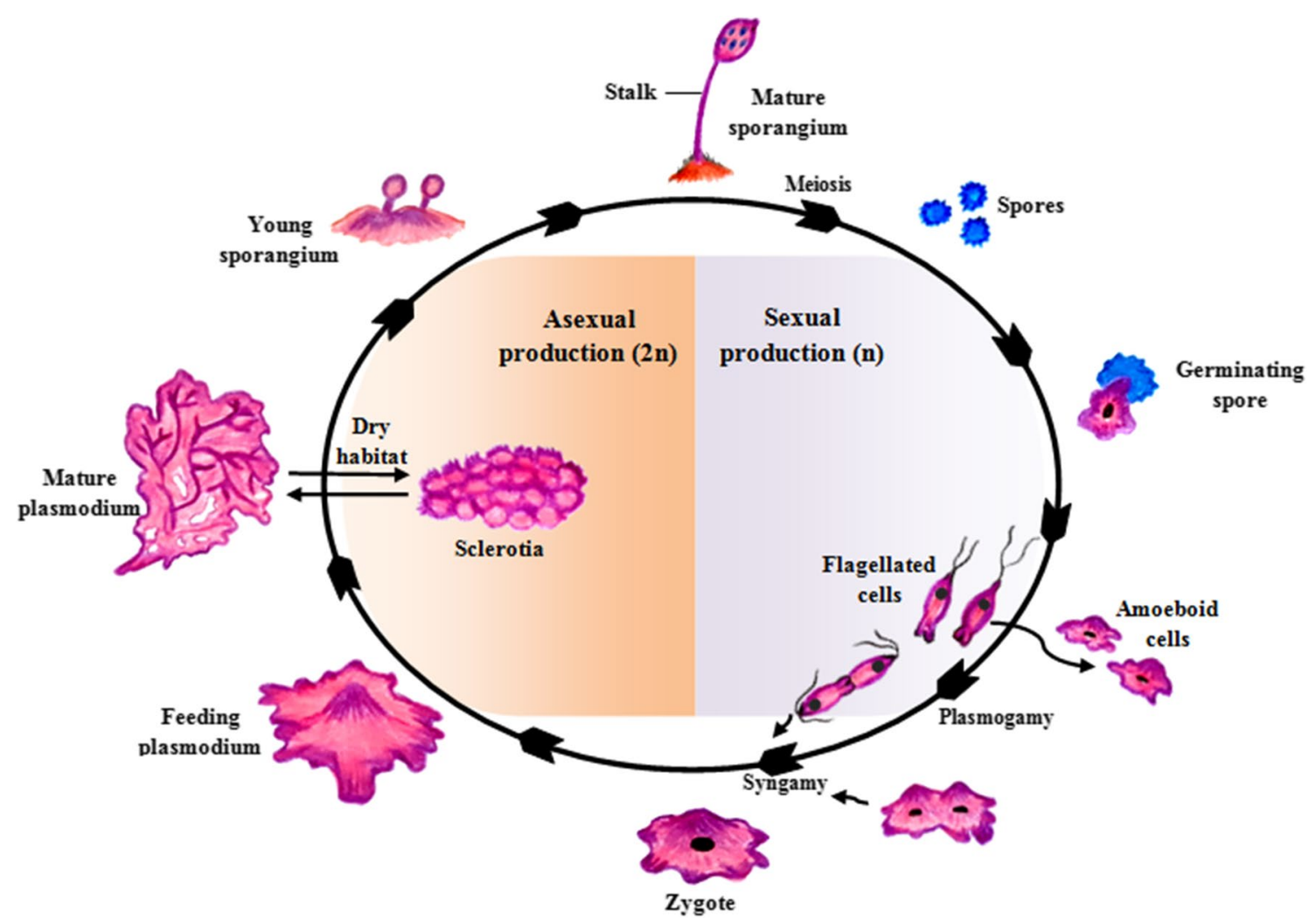

Fig. 1 The life cycle of a plasmodial slime mold includes sexual and asexual reproduction 

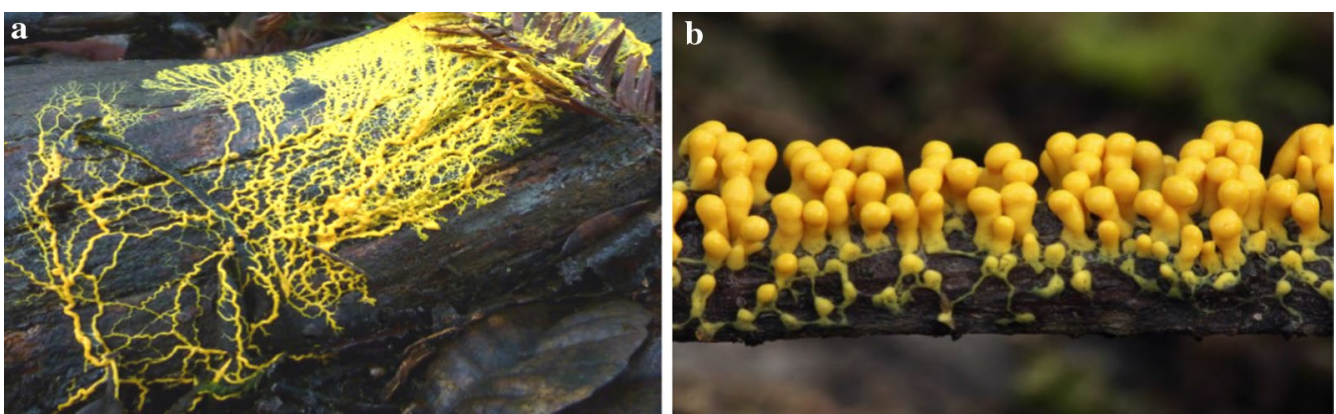

Fig. 2 a Plasmodium of the slime mold Physarum sp. b Sporangia of Physarum polycephalum (https://calphotos.berkeley.edu)

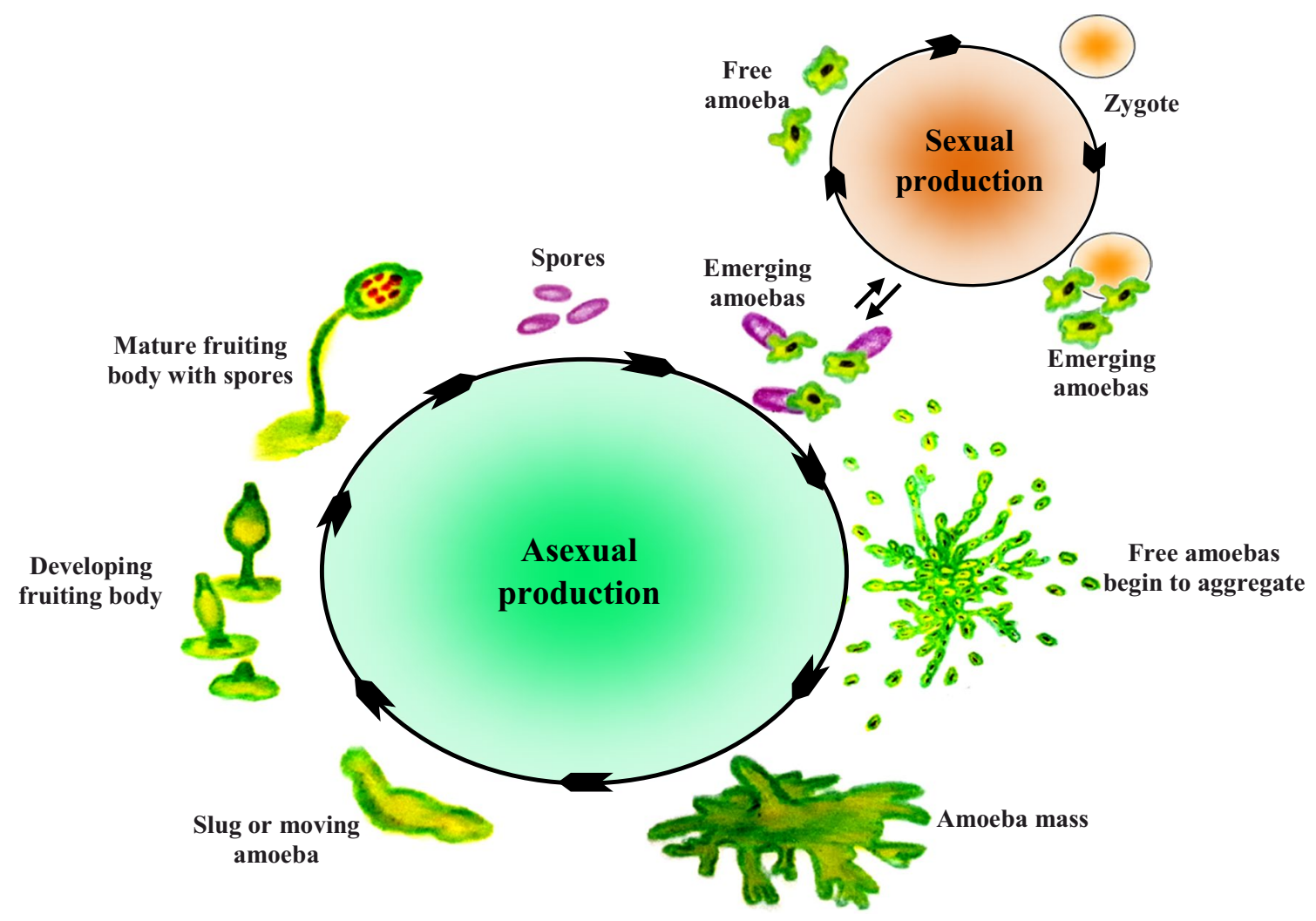

Fig. 3 Life cycle of a cellular slime mold

There are different natural sources of antimicrobial agents, such as filamentous bacteria actinomycetes (more than $50 \%$ of all antibiotics are produced by these microorganisms), non-filamentous bacteria (10-15\%) (Demain 2014; Salehghamari et al. 2015), microscopic fungi (about 20\% of all antibiotics are produced by filamentous fungi) (Demain 2014), slime molds, algae (Ibrahim and Lim 2015; Pane et al. 2015), plants (Abreu et al. 2012; Tafakori and Nasiri 2018; Eftekhar et al. 2005), animals
(Primon-Barros and José Macedo 2017; Han et al. 2011), and other natural sources.

There are different approaches for effective drug discovery programs: bioactive-guided screening, chemical screening, target-oriented screening, the use of unexplored strains, genome mining (using next-generation DNA sequencing), and activation of silent gene clusters (Wohlleben et al. 2016). Among different natural sources mentioned above, some have received extra attention, 

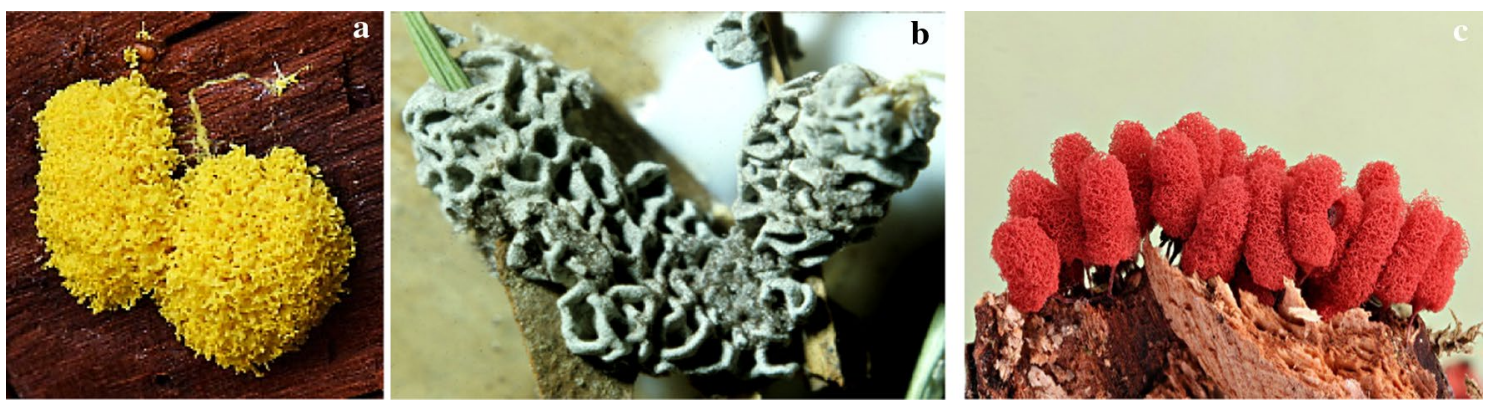

Fig. 4 a Fuligo septica, b Physarum gyrosum c Arcyria denudata (https://www.naturepl.com, https://www.discoverlife.org)

such as actinomycetes, microscopic fungi, and plants. However, the others, such as slime molds, have not been taken into account and can be considered unexplored strains. Therefore, this article has focused on the potential of these creatures as an alternative source of antibiotics.

\section{Slime molds}

Slime molds are protists with two stages in their life cycles. In one stage, they behave like protozoa (amoeba) while acting like fungi in the other. In the protozoan phase, they engulf food particles, other microbes and consuming decaying vegetation. These microorganisms are included in two groups: acellular slime molds (Myxogastria) and cellular slime molds (Dictyostelium) (Willey et al. 2014). Recently, slime molds have been known as good resources of natural compounds with bioactivity. Dembitsky et al. (2005) reported almost 100 natural compounds from only one of them, namely Myxomycetes. Some of these metabolites were bioactive compounds. The physiology and biochemistry of Myxomycetes have considered, but their secondary metabolites have remained virtually unknown. Some of these metabolites have been shown to possess antioxidant, cytotoxic, and antibacterial activities. This review focused on bioactive compounds with antibiotic activity.

\section{Slime molds types}

\section{Acellular slime molds}

The life cycle of this group of slime molds encompasses two strikingly different trophic (feeding) stages. The plasmodium structure, consisting of a distinctive multinucleate mass, involves as many as 10,000 dividing nuclei without individual cell membranes. This colorful protoplasm creeps along in amoeboid fashion over moist, cool, and shaded places, such as within cracks of decomposing wood, underneath the partially decayed bark of tree trunks and stumps, or other organic matter in high humidity condition, and in leaf debris on the forest floor which degrades and feeding by endocytosis (Willey et al. 2014; Dembitsky et al. 2005). The other stage of its life cycle starts when plasmodium mass is starved or dried. At this time, the plasmodium typically differentiates and develops fruiting bodies containing stalks with cellulose walls. Fruiting bodies are resistant to environmental stresses and contain spores (Willey et al. 2014).

The spores are, for most species, apparently winddispersed (Dembitsky et al. 2005). Under favorable conditions, spores germinate, and haploid amoebae flagellate cells are released. These cells fuse, forming zygotes. Then, these diploid cells feed, and nuclei divide asynchronously to form the multinucleate plasmodium
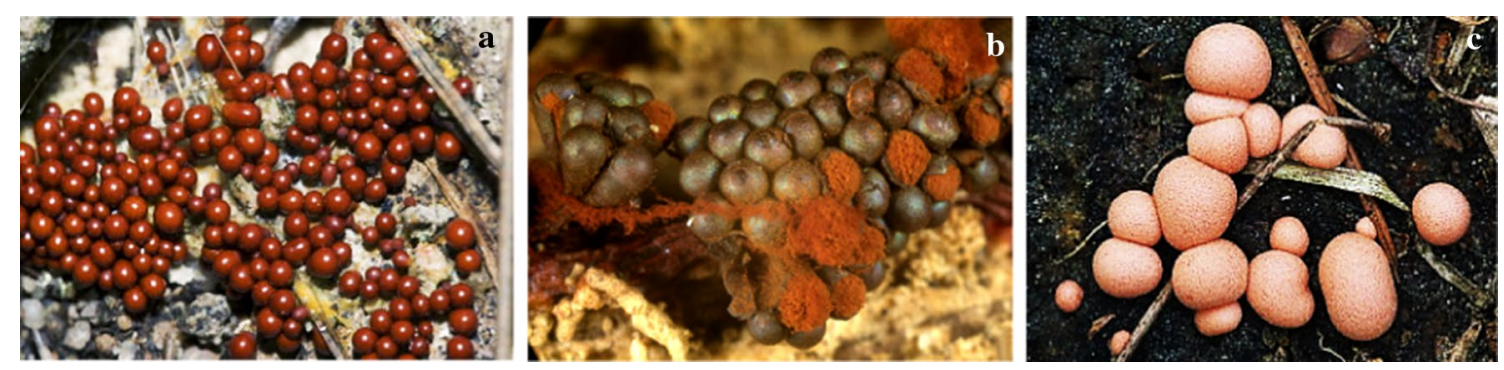

Fig. 5 a Leocarpus fragilis, b Metatrichia vesparium, c Lycogala epidendrum (https://www.discoverlife.org, https://www.naturepl.com) 

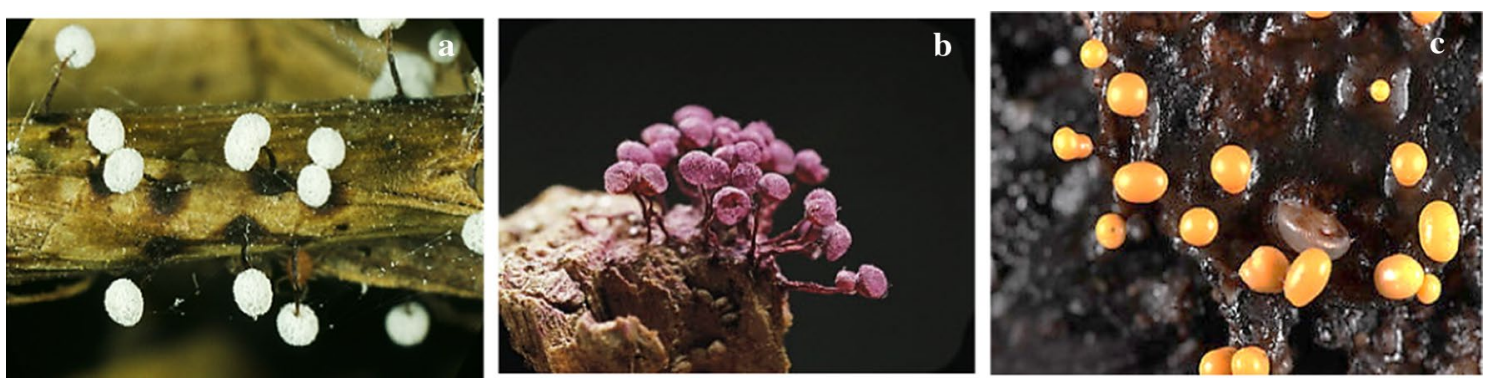

Fig. 6 a Didymium bahiense, b Cribraria purpurea, c Trichia varia (https://www.discoverlife.org, https://www.naturepl.com)

(Willey et al. 2014). Figure 1 illustrates the life cycle of acellular slime molds.

Myxomycetes are among the well-known classes of acellular slime molds that produce a large number of metabolites (Dembitsky et al. 2005). These metabolites were directly extracted from fruiting bodies. Thus, in vitro cultivation of Myxomycetes is a solution to produce a massive amount of fruiting bodies. Among Myxomycetes, most in vitro cultured species belong to the genera Physarum and Didymium (Dembitsky et al. 2005). Figure 2 illustrates the plasmodium form and sporangia of the Physarum.

\section{Cellular slime molds}

This group of slime molds has a complex life cycle involving true multicellularity, called pseudoplasmodium, which differs from the acellular slime mold's true plasmodium. It consists of an aggregated mass of individual amoebas that are able to migrate as large, motile, multicellular slugs. Actually, when the starved cells release molecular signals, cAMP, and a specific glycoprotein, the other cells sense these molecules and aggregate around the signal-producing cells (Willey et al. 2014). Ultimately, some of the amoebae cells sacrifice themselves and differentiate to the dead vacuolated stack that produces fruiting bodies containing countless and unicellular spores. Under favorable conditions, released spores germinate and release separate vegetative amoebae that feed on bacteria and yeasts. After running out of food and starvation, the amoebae aggregate to form pseudoplasmodium again (Bonner and Lamont 2005). Figure 3 shows the life cycle of cellular slime mold, Dictyostelium discoideum, an attractive model species.

\section{Antibiotics from slime molds}

This part of the article focuses on antimicrobial agents from slime molds according to the dates of reports. The first report on antibiotics from slime molds, has been published more than 73 years ago. In 1948, two anthraquinone acids, derivatives of an aromatic organic compound as pigment, were isolated from Fuligo septica (Fig. 4a) with antibiotic activity (Loquin and Prevot 1948). These compounds are aromatic yellow pigment of F. septica. According to Sobels (1950), mucous secretions or aqueous extracts of Licea flexuosa plasmodium in pure culture and in association with Torulopsis laurentii (a yeast species) inhibited the growth of Cladosporium herbarum, Penicillium sp., certain bacteria, and yeasts.

Antibacterial products from Physarum gyrosum plasmodium (Fig. 4b) on agar plate have been extracted and partially purified. It had effected on $S$. aureus, $B$. cereus, B. subtilis, E. coli, and $P$. aeruginosa (Considine and Mallette 1965). A butanolic and fractionated (pure
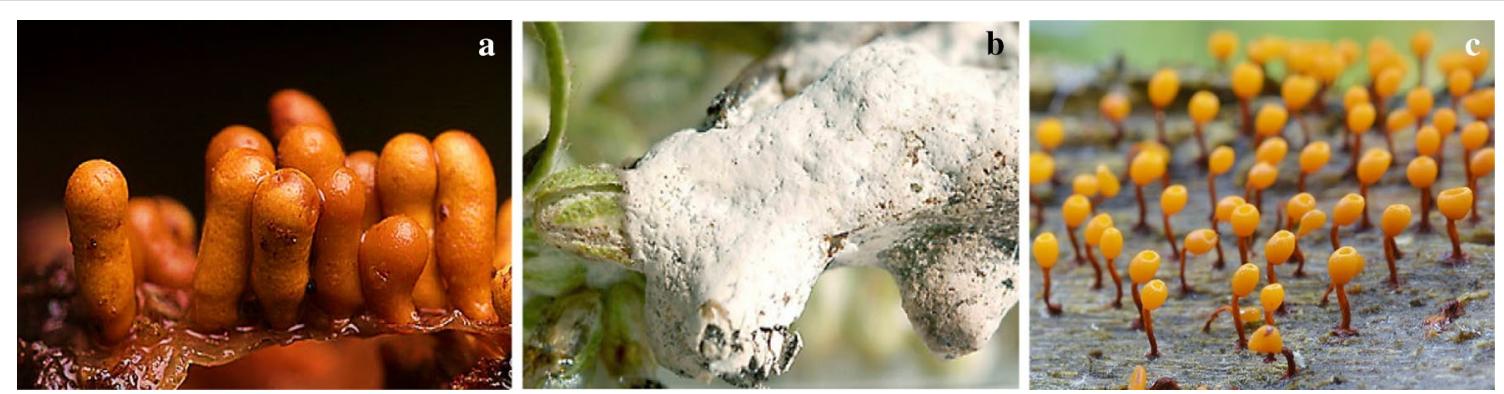

Fig. 7 a Trichia favoginea, b Fuligo cinerea, c Physarella oblonga (http://www.sanamyan.com/myxomycetes, https://www.discoverlife.org, http:// mycoweb.ru) 

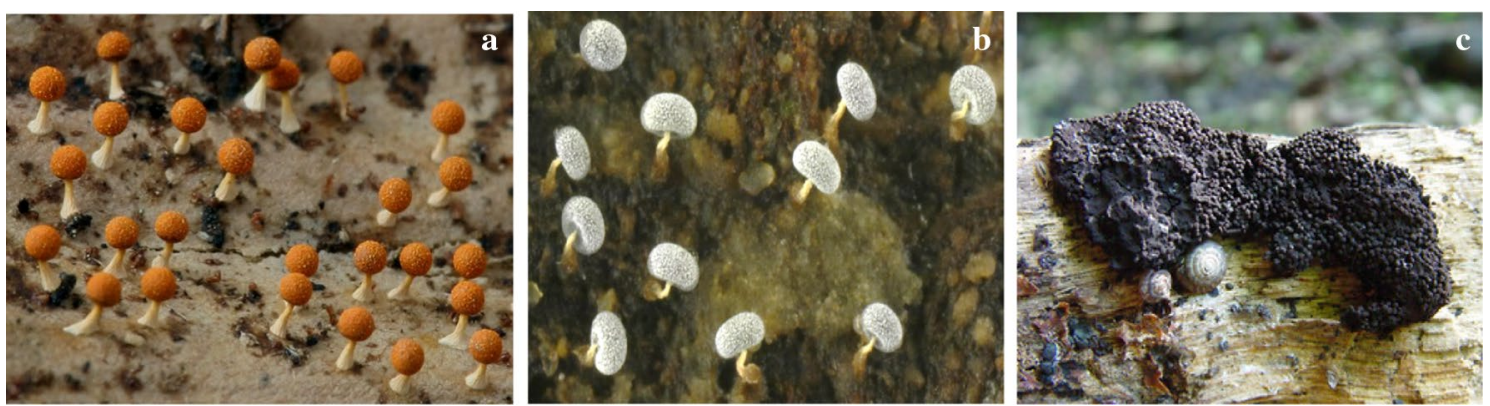

Fig. 8 a Physarum melleum. b Physarum album, c Symphytocarpus amaurochaetoides. (https://www.discoverlife.org)

heterocyclic antibiotic D-1) extract of plasmodium form of Physarum gyrosum had antibacterial effects against gram-positive bacteria, S. cerevisiae, Mycobacterium 156, Torulopsis sphaerica and intermediate effect on E. coli. Pure antibiotic was effective against B. cereus (Schroeder and Mallette 1973).

Steglich et al. (1980) extracted and isolated pigment from the fruiting bodies of the slime mold, Arcyria denudata (Fig. 4c) with methanol, which makes them red and yellow. These main pigments were bisindolylmaleimides and named arcyriarubin B (1), C (2), arcyriaflavin B (3), C (4), and arcyrioxepin A (5), among which compounds 1 , 2 , and 5 showed medium inhibiting zone against $B$. brevis and B. subtilis in the plate diffusion assay.

Casser et al. (1987) also isolated a yellow pigment, Fuligorubin A, from the plasmodia of Fuligo septica, which is the first tetramic acid derivative to be isolated from slime molds. These components have the butenolide structure with antibiotics, antitumor, and mycotoxins properties. The acyltetramic acids are also responsible for the orange-yellow color of plasmodia from Leocarpus fragilis (Fig. 5a). These components have previously been isolated from streptomycetes and fungi. Three possible roles are attributed to acyltetramic acids: first, as the protector of plasmodia of slime molds against the attack of microorganisms; second, as photoreceptors; and third, as metal chelating agents (Steglich 1989).

Kopanski et al. (1987) isolated a red pigment of the fruit bodies, namely vesparione, a naphtha[2,3-b]pyrandione derivative, from another myxomycete, Metatrichia vesparium (Fig. 5b). This pigment had antibiotic properties. Lycogarubins A-C, three novel dimethyl pyrrole dicarboxylate, were isolated from Myxomycetes Lycogala epidendrum (Fig. 5c). Lycogarubin C showed moderate anti-HSV-I virus activity (Hashimoto et al. 1994). Wang et al. (2017) also reported that lycogalinosides A and B, two compounds isolated from L. epidendrum, showed inhibitory activities against gram-positive bacteria. Lycogarubins A-C are pigment and polycyclic compounds.

Chiappeta et al. (1999) examined the influence of methanol pH on the extraction of the fruiting bodies of F. septica. The extracts were obtained at $\mathrm{pH} 2$ and 7, but not at $\mathrm{pH} 9$, had antimicrobial activity against $S$. aureus, B. subtilis, M. luteus and C. albicans. AB0022A, a highly substituted aromatic and a Dibenzofuran, was isolated from the Dictyostelium purpureum K1001, a cellular slime mold, and exhibited the growth inhibition of different gram-positive bacteria, such as $S$. aureus and S. pyogenes (Sawada et al. 2000).
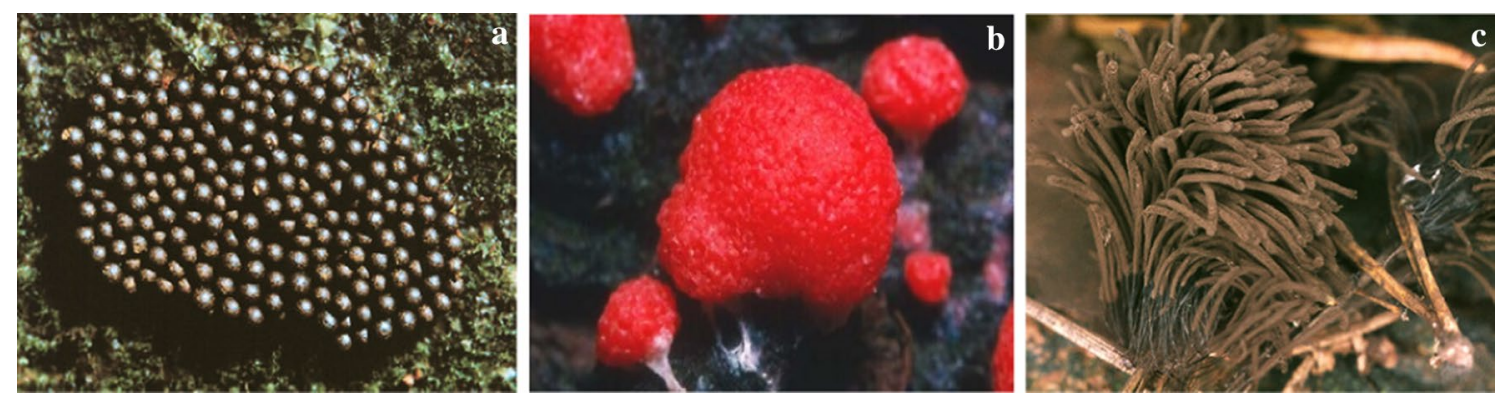

Fig. 9 a Lindbladia tubulina Fr, b Tubifera ferruginosa (Batsch) Gmelin, c Stemonitis fusca Roth (https://www.discoverlife.org) 


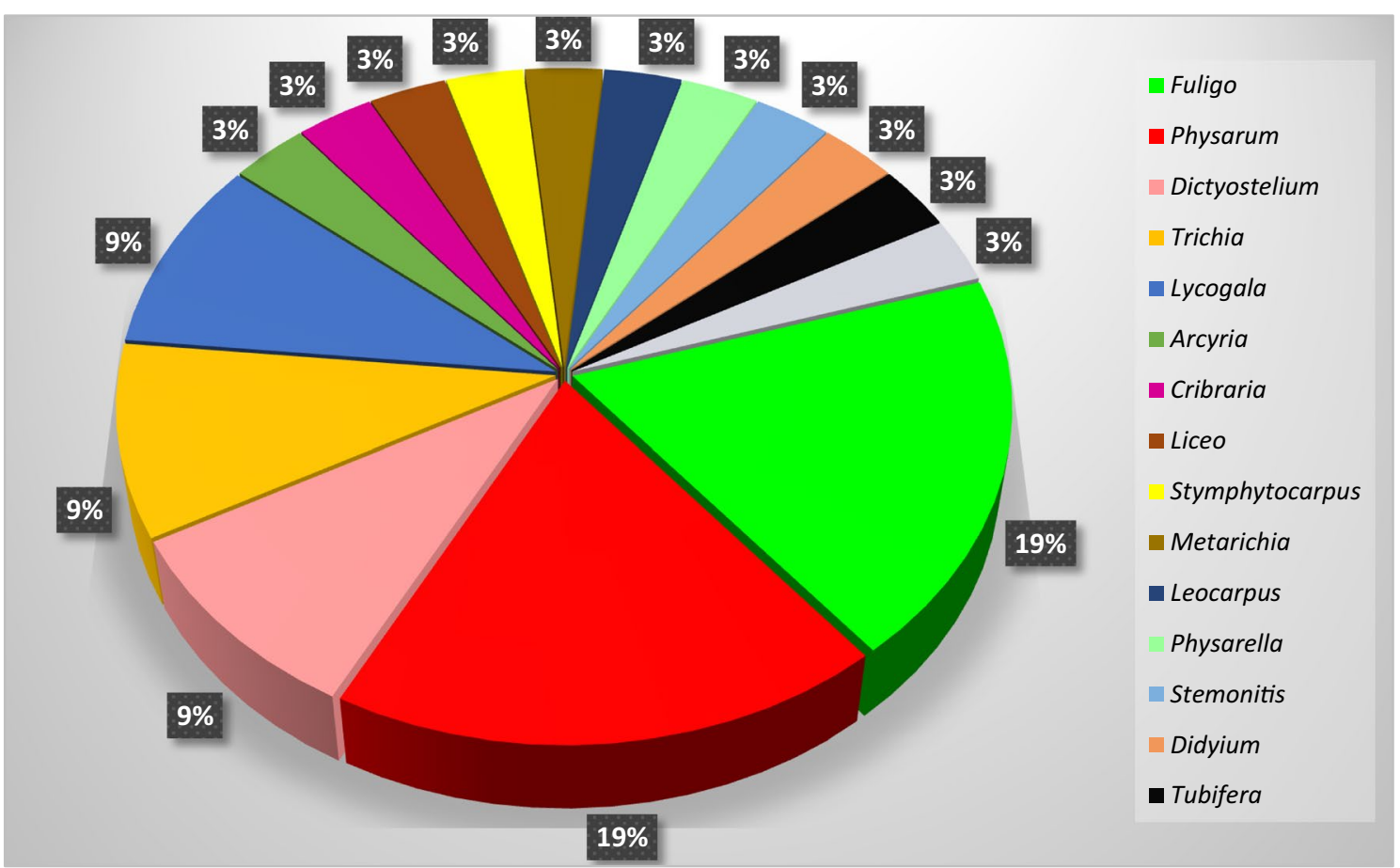

Fig. 10 The pattern of distribution of the reported slime molds producing antimicrobial agents

Misono et al. (2003) isolated a new glycerolipid, namely Bahiensol, from the plasmodium form of myxomycete Didymium bahiense var. bahiense (Fig. 6a). The molecular formula of Bahiensol was $\mathrm{C}_{19} \mathrm{H}_{40} \mathrm{O}_{5}$, and it showed non-significant activity against $B$. subtilis. The inhibition zone diameter was $12.5 \mathrm{~mm}$ for $500 \mathrm{mg}$ Bahiensol per paper disc ( $8 \mathrm{~mm}$ in diameter).

Naoe et al. (2003) isolated Cribrarione A from a myxomycete Cribraria purpurea (Fig. 6b). This compound was a dihydrofuran naphthoquinone pigment, and its structure was determined by mass spectrometric data. In its Heteronuclear Multiple Bond Correlation spectrum, the $1 \mathrm{H}-13 \mathrm{C}$ long-range couplings constants an intramolecular hydrogen bond were revealed. Cribrarione A showed antibacterial activity against $B$. subtilis. The diameter of the inhibition zones was $11 \mathrm{~mm}$ (including $8 \mathrm{~mm}$ paper disc) at $5 \mu \mathrm{g}$ per paper disc.

Rare fatty acids with $\Delta^{5,9}$-position of two double bonds have been identified in two Myxomycetes, Trichia varia (Fig. 6c) and T. favoginea (Fig. 7a) for the first time (Dembitsky et al. 2005). The compounds with similar structures were particularly active against Gram-positive bacteria, such as $S$. aureus and $S$. faecalis, but this was not true about gram-negative bacteria (Carballeira et al. 1997). Kehokorins A, a polycyclic pigment, extracted from Trichia favoginea var. persimilis, exhibited inhibition zone with $10.1 \mathrm{~mm}$ at $50 \mu \mathrm{g}$ per disc $(8 \mathrm{~mm}$ in diameter) against $S$. aureus but had no activity against $B$. subtilis at that concentration (Kaniwa et al. 2006). Fuligo cinerea (Fig. 7b) produces an unusual metabolite with glycosidic dibenzofuran structure, Fulicineroside. It has exhibited a high level of activity against Gram-positive bacteria (Rezanka et al. 2005). The plasmodial extracts of Physarella oblonga (Fig. 7c) showed an antiparasitic activity against epymastigote forms of Trypanosoma cruzi, while one of the used controls had significantly lower activity. On the other hand, myxomycete Physarum melleum, (Fig. 8a) showed antifungal activity against the phytopathogen F. oxysporum (Herrera et al. 2011).

A crude extract of $F$. septica, was shown to have significant inhibitory effects on $E$. coli and B. subtilis, with inhibition rates of $68.00 \%$ and $59.45 \%$, respectively. However, this extract had only a minor effect on $S$. aureus and $S$. typhimurium and no effect on P. pyocyaneum (Jiang et al. 2014). A secondary metabolite of SteelyA polyketide synthase, 4-Methyl-5-pentylbenzene-1,3-diol (MPBD), controlled the aggregation of individual cells and spore maturation of Dictyostelium discoideum. This compound had antimicrobial activities toward E. coli and B. subtilis (Murata et al. 2016). Exopolysaccharides (EPS) from $P h$. oblonga and Ph. polycephalum showed significant antimicrobial activities, especially against Candida albicans with an inhibition zone of $20 \mathrm{~mm}$. MICs of this yeast were found to be $2560 \mu \mathrm{g} / \mathrm{ml}$ for EPS from Phy. Oblonga, 
Table 2 Antibiotics from slime molds

\begin{tabular}{|c|c|c|}
\hline Antibiotic name & Slime molds & Reference \\
\hline Anthraquinonic acids (acyltetramic acids) & Fuligo septica & Loquin and Prevot (1948) \\
\hline Mucous secretions or aqueous extracts of plasmodium & Liceo flexuosa & Sobels (1950) \\
\hline Plasmodium extract & Physarum gyrosum & Considine and Mallette (1965) \\
\hline $\begin{array}{l}\text { A butanolic and fractionated (pure heterocyclic antibiotic D-1) } \\
\text { extract of plasmodium }\end{array}$ & Physarum gyrosum & Schroeder and Mallette (1973) \\
\hline Arcyriarubins $(B, C)$, arcyriaflavins $(B, C)$, arcyrioxepin $A$ & Arcyria denudata & Steglich et al. (1980) \\
\hline Fuligorubin A (acyltetramic acids) & Fuligo septica & Casser et al. (1987) \\
\hline Vesparione (naphtha[2,3-b]pyran dione derivative) & Metatrichia vesparium & Kopanski et al. (1987) \\
\hline Acyltetramic acids & Leocarpus fragilis & Steglich (1989) \\
\hline Lycogarubins A-C (dimethyl pyrroledicarboxylate) & Lycogala epidendrum & Hashimoto et al. (1994) \\
\hline Methanolic extract of fruiting body & Fuligo septica & Chiappeta et al. (1999) \\
\hline AB0022A & Dictyostelium purpureum K1001 & Sawada et al. (2000) \\
\hline Bahiensol (A glycerolipid) & Didymium bahiense var. bahiense & Misono et al. (2003) \\
\hline Cribrarione A (A dihydrofuranonaphthoquinone) & Cribraria purpurea & Naoe et al. (2003) \\
\hline Fatty acids with $\Delta^{5,9}$-position of two double bonds (two) & $\begin{array}{l}\text { Trichia Favogina } \\
\text { Trichia varia }\end{array}$ & Dembitsky et al. (2005) \\
\hline Fulicineroside (A glycosidic dibenzofuran) & Fuligo cinerea & Rezanka et al. (2005) \\
\hline Kehokorins A & Trichia favoginea var. persimilis & Kaniwa et al. (2006) \\
\hline Plasmodial extract & Physarella oblonga & Herrera et al. (2011) \\
\hline Plasmodial extract & Physarum melleum & Herrera et al. (2011) \\
\hline Crude extract & Fuligo septica & Jiang et al. (2014) \\
\hline 4-methyl-5-pentylbenzene-1,3-diol (MPBD) & Dictyostelium discoideum & Murata et al. (2016) \\
\hline Lycogalinosides A and B & Lycogala epidendrum & Wang et al. (2017) \\
\hline $\begin{array}{l}\text { EPS } \\
\text { EPS }\end{array}$ & $\begin{array}{l}\text { Physarella oblonga } \\
\text { Physarum polycephalum }\end{array}$ & Huynh et al. (2017) \\
\hline Ethanol, methanol and dichloromethane extract & Physarum album (Bull.) & Sevindik et al. (2018) \\
\hline Differentiation-inducing factors (DIFs) & Dictyostelium discoideum & Kubohara et al. (2019) \\
\hline Ethanol, methanol and dichloromethane extracts & $\begin{array}{l}\text { Symphytocarpus amaurochaetoides } \\
\text { Nann.-Bremek., } \\
\text { Lindbladia tubulina Fr., } \\
\text { Fuligo septica (L.) FH Wigg., } \\
\text { Stemonitis fusca Roth., } \\
\text { Tubifera ferruginosa (Batsch) JF Gmel., } \\
\text { Lycogala epidendrum L. Fr }\end{array}$ & Baba et al. (2020) \\
\hline
\end{tabular}

and $1280 \mu \mathrm{g} / \mathrm{ml}$ for EPS from Ph. Polycephalum (Huynh et al. 2017).

In 2018, Sevindik et al. reported antibacterial and antifungal activity of ethanolic, methanolic and dichloromethanic extracts of sporophore stage Physarum album (Fig. 8b) with the highest activity against Acinetobacter baumannii. They used modified agar dilution method on Staphylococcus aureus, S. aureus MRSA, Enterococcus faecalis, Escherichia coli, Pseudomonas aeruginosa, Klebsiella pneumoniae, Acinetobacter baumannii, Candida albicans, C. krusei, and C. glabrata.

The chlorinated alkylphenone differentiation-inducing factors (DIFs) induce stalk cell developing in D. discoideum. These compounds and their derivatives exhibited several biological activities, including antibacterial properties. Many of these DIF derivatives strongly inhibited the growth of MRSA and VAR, such as E. faecalis and $E$. faecium, and suppressed the growth of the other Gram-positive bacteria, such as S. aureus and B. subtilis, at MICs within the sub-micromolar to the low-micromolar range. In contrast, none of these DIF derivatives had any significant effect on the growth of the Gram-negative bacterium E. coli (Kubohara et al. 2019). Ethanol, methanol and dichloromethane extracts of six myxomycete species, isolated from turkey, were tested on bacteria and fungi. Three kinds of extracts from Symphytocarpus amaurochaetoides (Fig. 8c), Lindbladia tubulina (Fig. 9a), F. septica and Tubifera ferruginosa (Fig. 9b) had antibacterial and antifungal effects. But these extracts from 
<smiles>O=C(O)c1cccc2c1C(=O)c1ccccc1C2=O</smiles>

Anthraquinone-1-carboxylic acids<smiles>O=c1[nH]c(=O)c2c3[nH]c4ccccc4c3[nH]c3ccccc3c1=2</smiles>

Arcyriaflavin A<smiles>O=C1NC(=O)C(c2c[nH]c3ccccc23)=C1c1c[nH]c2ccccc12</smiles>

Arcyriarubin B<smiles>O=C1NC(=O)c2c1c1c3ccccc3[nH]c1c1[nH]c3cc(O)ccc3c21</smiles>

Arcyriaflavin B<smiles>Cc1ccc2c(C3=C(c4c[nH]c5cc(O)ccc45)C(=O)NC3=O)c[nH]c2c1</smiles>

Arcyriarubin C<smiles>O=c1[nH]c(=O)c2c1c1ccc(O)cc1[nH]c1c3[nH]c4cc(O)ccc4c3c12</smiles>

Arcyrioxepin C<smiles>C/C=C/C=C/C=C/C=C/C=C/C=C/C(=O)C1=C(O)[C@@](CCC(=O)O)(CCC(C)C)N(C)C1=O</smiles><smiles>COc1ccc(-c2c(O)cc3c(oc4ccc(OCC(C)C)c(OC)c43)c2OC)cc1</smiles>

Kehokorins A<smiles>CC(=O)C1=C(O)[C@H](Cc2ccc(O)cc2)NC1=O</smiles><smiles>C/C=C/C=C/C=C/C(=O)C1=C(O)C(Cc2ccc(O)cc2)NC1=O</smiles><smiles>C/C=C/C=C/C/C=C/C=C/C=C/C(=O)C1=C(O)C(c2ccc(O)cc2)N(C)C1=O</smiles>

Acyltetramic acid derivatives<smiles>COC(=O)c1[nH]c(C(=O)OC)c(-c2c[nH]c3ccc(O)cc23)c1-c1c[nH]c2ccc(O)cc12</smiles>

lycogarubins A<smiles>COC(=O)c1[nH]c(C(=O)OC)c(-c2c[nH]c3ccccc23)c1-c1c[nH]c2ccccc12</smiles>

lycogarubins B<smiles>C=C(OC)c1[nH]c(C(=O)OC)c(-c2c[nH]c3ccc(O)cc23)c1-c1c[nH]c2ccccc12</smiles>

lycogarubins $\mathrm{C}$

Fig. 11 Pigment components from slime molds with antimicrobial activity 
<smiles>CC1(C)C=CC2=C(Oc3ccccc3O2)O1</smiles>

Naphtho(2,3-b)pyran dione<smiles>CCCCCC(=O)c1c(OC)c(Cl)c2oc3c(Cl)c(OC)c(Cl)c(O)c3c2c1O</smiles>

$\mathrm{AB} 0022 \mathrm{~A}$<smiles>CCCCCc1cc(O)cc(O)c1C</smiles>

MPBD<smiles>CCCCCC/C=C/CC/C=C/CCCC(=O)O</smiles>

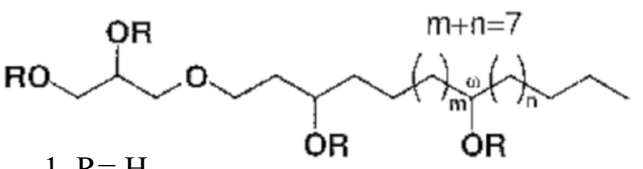

$1 \mathrm{R}=\mathrm{H}$

$2 \mathrm{R}=\mathrm{COCH} 3$

Fatty acid

Bahiensols

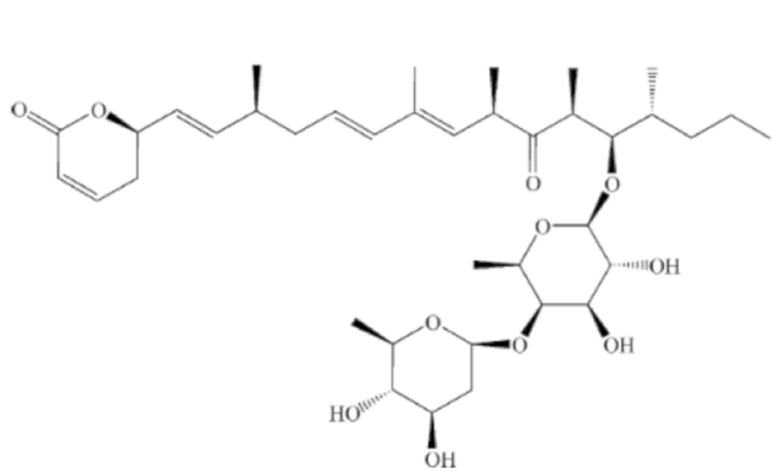

Lycogalinoside A,B

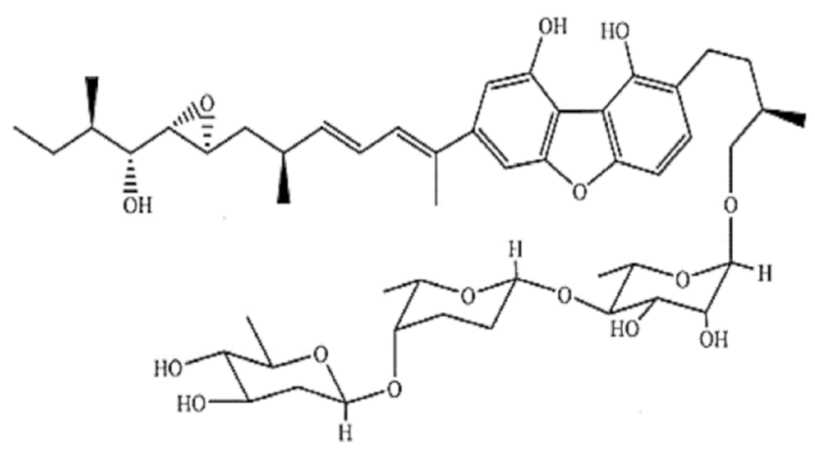

Fulicineroside

Fig. 12 Non-pigment components from slime molds with antimicrobial activity

Stemonitis fusca (Fig. 9c) and L. epidendrum had lower antimicrobial activity (Baba et al. 2020).

\section{The distribution pattern of the different slime molds producing antibiotic compounds}

In this review, I summarized the all reports related to slim molds producing antibiotic compounds. These include 31 slime molds with different agents, and some of them were crude extracts. It is noteworthy that only two genera of Myxomycetes, Fuligo, and Physarum, involve $38 \%$ of total slime molds studied as antimicrobial sources. Three other frequent genera, Dictyostelium, Trichia, and Lycogala, each with 9\% of frequency, involve $27 \%$ of total slime molds producing antibiotics. In addition, these five genera, include $65 \%$ reported. The remaining $35 \%$ of the slime molds producing antimicrobial agents are scattered across 11 other genera, each one 3\%. Figure 10 shows the distribution pattern of these slime molds. Except for one gene, Dictyostelium a cellular slime mold, the other genera are Myxomycete, true or acellular slime molds. Because these creatures usually present and sometimes abundant in terrestrial ecosystems and are the only macroscopic slime molds, so they found easier (Dembitsky et al. 2005). So only $9 \%$ of isolated antibiotics, are from cellular slime molds and $91 \%$ are from acellular slime molds.

\section{Pigments of slime molds are predominant in antimicrobial activity}

According to Table 2, 39.53\% of isolated antimicrobial agents from slime molds are crude extracts (involve EPS) and $60.46 \%$ are pure agents. 26 pure antimicrobial agents were isolated from slime molds. Figure 11 shows the chemical structure of 17 compounds of these pure 
antimicrobial agents. It is significant that all of these compounds are pigments, so $65.38 \%$ of isolated pure agents are pigments of slime molds and this high dependency ratio is a valuable guide in the antimicrobial agents' discovery field. Other microbial pigments, such as flavins, melanins, quinones, violacein carotenoids, indigo, and monascins from fungal and bacterial sources, also serve as antimicrobial agents against a wide range of pathogens (Rao et al. 2017). The mechanism of antimicrobial activity of some microbial pigments has been made. For example, Prodigiosin of Vibrio sp. DSM 14379 has an effect on $E$. coli with decreasing respiration, inhibition of protein and RNA synthesis, and membrane leakage (Danevcic et al. 2016).

In Fig. 12, also illustrated non-pigment pure antimicrobial agents from slime molds. Two kinds of compounds, Fatty acid and bahiensols derivatives, had no cyclic structure. The other pure antimicrobial agents from slime molds are cyclic structures. Natural aromatic and cyclic chemicals are in great demand in different fields such as pharmaceuticals, food, perfumes, and cosmetics. For example, the antimicrobial activity of various essential oils from plants, with aromatic structure, reported many times (Androutsopoulou et al. 2021). This point also could be a guide in drug discovery fields.

\section{Challenges and perspectives}

The first antibiotic, penicillin, was identified in the fungus Penicillium notatum. Since that discovery, most of the antibiotics identified, have been isolated from fungi and Actinobacteria (Kubohara et al. 2019; Durand et al. 2019). However, the emergence of drug-resistant bacteria, such as MRSAs and VREs, has been attributed to the intensive use or the use of subtherapeutic dosing of antibiotics in medicine. Therefore, searches for bio-resources that produce novel antimicrobials or new antibiotic molecules from old sources are required. However, the investigative studies of slime molds expressed above indicated that these protists have a special life cycle and are estimated to produce many valuable secondary metabolites with unique chemical structures. It has been predicted that these metabolites could represent a potential source of natural active products, such as antibiotics, which offers a broad field of further studies (Kubohara et al. 2019; Kubohara and Kikuchi 2019; Sasaki et al. 2020).

Table 2 provides the process of these investigations. As mentioned, only a few known species of slime molds have been investigated so far. This is due to the difficult cultivation of slime molds. Therefore, Sihui and collaborates mentioned that for further progress in isolation of the bioactive compounds, the development of cultivation strategies to grow slime molds is crucial. They provided different culture methods including pure culture, feeding culture, liquid culture, moist chamber culture and hanging drop culture. But all methods have disadvantages. In pure culture, most slime molds do not grow on laboratory medium. In feeding culture, which compared to pure culture, bacteria or yeast are added to the medium as food, the plasmodia are often mixed with bacteria and yeasts. Liquid culture is not suitable for most slime molds. In the moist chamber culture method, the whole life cycle cannot be observed and artificially selected for extraction. The hanging drop method is only for spore germination and is not suitable for the whole life cycle (Li et al. 2020).

Slime molds have a special life cycle and are predicted to produce many valuable metabolites with unique chemical structures. Hence, these protists have been predicted to produce a potential source of natural active products. However, further studies are still needed since the number of species investigated so far is still relatively small. So the biggest challenge for obtaining new antimicrobial compounds from these valuable natural sources is to find effective laboratory culture methods.

\section{Acknowledgements}

Not applicable.

Authors' contributions

The author read and approved the final manuscript.

Funding

Not applicable.

Availability of data and materials

Not applicable.

\section{Declarations}

Ethics approval and consent to participate

This article does not contain any studies with human participants or animals performed by any of the authors.

Consent for publication

The author consent for publication.

Competing interests

There is no conflict of interest.

Received: 4 June 2021 Accepted: 12 June 2021

Published online: 23 June 2021

References

Abreu AC, McBain A, Simões M (2012) Plants as sources of new antimicrobials and resistance-modifying agents. Nat Prod Rep 29(9):1007-1021

Ahmad FB, Cisewski JA, Miniño A, Anderson RN (2021) Provisional mortality data_United States, 2020. MMWR Morb Mortal Wkly Rep. Published March 31, 2021. https://www.cdc.gov/mmwr/volumes/70/wr/mm701 4e1.htm?s_cid=mm7014e1_w

Amenu D (2014) Antimicrobial resistance for enteric pathogens isolated from acute gastroenteritis patients. World J Nat Appl Sci 1(1):1-14

Androutsopoulou C, Lamari FN, Christopoulou SD, Hahalis P, Kotsalou C, Vantarakis A (2021) Evaluation of essential oils and extracts of rose geranium 
and rose petals as natural preservatives in terms of toxicity, antimicrobial, and antiviral activity. Pathogens 10:494

Baba H, Sevindik M, Dogan M, Akgul H (2020) Antioxidant, antimicrobial activities and heavy metal contents of some myxomycetes. Fresenius Environ Bull 9(09):7840-7846

Bonner JT, Lamont DS (2005) Behavior of cellular slime molds in the soil. Mycologia 97(1):178-184

Carballeira NM, Reyes ED, Sostre A, Rodriguez AD, Rodriguez JL, Gonzalez FA (1997) Identification of the novel antimicrobial fatty acid (5Z,9Z)14-methyl-5,9-pentadecadienoic acid in Eunicea succinea. J Nat Prod 60:502-504

Casser I, Steffan B, Steglich W (1987) The chemistry of the plasmodial pigments of the slime mold Fuligo septica (Myxomycetes). Angew Chem Int Ed 26(6):586-587

Cheesbrough M (2006) District laboratory practice in tropical countries, 5th edn. Cambridge University Press, Cambridge

Chiappeta AD, de Sena KX, Nascimento SC, Rocha CS, Cavalcanti LD (1999) Influence of $\mathrm{pH}$ on the extraction of the bioactive substances of Fuligo septica (Myxomycetes). Phyton 65:7-11

Considine JM, Mallette MF (1965) Production and partial purification of antibiotic materials formed by Physarum gyrosum. Appl Microbiol 13:464-468

Danevcic T, Boric Vezjak M, Zorec M, Stopar D (2016) Prodigiosina multifaceted Escherichia coli antimicrobial agent. PLoS ONE 11(9):e0162412

Demain AL (2014) Importance of microbial natural products and the need to revitalize their discovery. J Ind Microbiol Biotechnol 41:185-201

Dembitsky VM, Rezanka T, Spizek J, Hanus LO (2005) Secondary metabolites of Slime Molds (Myxomycetes). Phytochemistry 66(7):49-769

Duin D, Paterson D (2016) Multidrug resistant bacteria in the community: trends and lessons learned. Infect Dis Clin N Am 30(2):377-390

Durand GA, Raoult D, Dubourg G (2019) Antibiotic discovery: history, methods and perspectives. Int J Antimicrob Agents 53:371-382

Eftekhar F, Yousefzadi M, Tafakori V (2005) Antimicrobial activity of Datura innoxia and Datura stramonium. Fitoterapia 76(1):118-120

Han FF, Liu YF, Xie YG, Gao YH, Luan C, Wang YZ (2011) Antimicrobial peptides derived from different animals: comparative studies of antimicrobial properties, cytotoxicity and mechanism of action. World J Microbiol Biotechnol 27(8):1847-1857

Harvey AL (2008) Natural products in drug discovery. Drug Discov Today 13(19-20):894-901

Hashimoto T, Yasuda A, Akazawa K, Takaoka S, Tori M, Asakawa Y (1994) Three novel dimethyl pyrroledicarboxylate, lycogarubins A-C, from the myxomycetes lycogala epidendrum. Tetrahedron Lett 35:2559-2560

Herrera NA, Rojas C, Franco-Molano AE, Stephenson SL, Echeverri F (2011) Physarella oblonga-centered bioassays for testing the biological activity of myxomycetes. Mycosphere 2(6):637-644

Huynh TTM, Phung TV, Stephenson SL, Tran HTM (2017) Biological activities and chemical compositions of slime tracks and crude exopolysaccharides isolated from plasmodia of Physarum polycephalum and Physarella oblonga. BMC Biotechnol 17:76-86

Ibrahim D, Lim SH (2015) In vitro antimicrobial activities of methanolic extract from marine alga Enteromorpha intestinalis. Asian Pac J Trop Biomed 5(9):785-788

Jiang N, Liu Y, Zhu YY, Wang Q (2014) Study on antibacterial activity of plasmodium and sclerotium from Fuligo septica. J Fungal Res 12(3):160-163 (In Chinese)

Kaniwa K, Ohtsuki T, Yamamoto Y, Ishibashi M (2006) Kehokorins A-C, novel cytotoxic dibenzofurans isolated from the myxomycete Trichia favoginea var. persimilis. Tetrahedron Lett 47:1505-1508

Kopanski L, Karbach G, Selbitschka G, Steglich W (1987) Fungal pigments, 53.-Vesparione, a Naphtho[2,3-b]pyrandione derivative from the slime mold Metatrichia vesparium (Myxomycetes). Liebigs Ann Chem 9:793-796

Kubohara Y, Kikuchi H (2019) Dictyostelium: an important source of structural and functional diversity in drug discovery. Cells 8:6

Kubohara Y, Oshima Y, Shiratsuchi Y, Ishigaki H, Takahashi K, Kikuchi H (2019) Antimicrobial activities of Dictyostelium differentiation-inducing factors and their derivatives. Biomolecules 9:163

Li S, Lin N, Wu B (2020) Laboratory culture and bioactive natural products of myxomycetes. Fitotrapia 146:104725
Loquin M, Prevot AR (1948) Etude de quelque antibiotiques produits par les myxomycetes. Ann Inst Pasteur 75:8-13

Misono Y, Ishibashi M, Ito A (2003) Bahiensol, a new glycerolipid from a cultured Myxomycete Didymium bahiense var. bahiense. Chem Pharm Bull 51(5):612-613

Murata C, Ogura T, Narita S, Kondo AP, Iwasaki N, Saito T, Usuki T (2016) Synthesis and SAR of 4-methyl-5-pentylbenzene-1,3-diol (MPBD), produced by Dictyostelium discoideum. Bioorganic Med Chem Lett 26:1428-1433

Naoe A, Ishibashi M, Yamamoto Y (2003) Cribrarione A, a new antimicrobial naphthoquinone pigment from a myxomycete Cribraria purpurea. Chem Inform 59(19):3433-3435

Pane G, Cacciola G, Giacco E, Mariottini GL, Coppo E (2015) Assessment of the antimicrobial activity of algae extracts on bacteria responsible of external otitis. Mar Drugs 13(10):6440-6452

Phillipson JD (2007) Phytochemistry and pharmacognosy. Phytochemistry 68(22-24):2960-2972

Primon-Barros M, José Macedo A (2017) Animal venom peptides: potential for new antimicrobial agents. Curr Top Med Chem 17(10):1119-1156

Rao M, Xiao M, Li W (2017) Fungal and bacterial pigments: secondary metabolites with wide applications. Front Microbiol 8:1113

Rezanka T, Hanus LO, Dembitsky VM (2005) The fulicineroside, a new unusual glycosidic dibenzofuran metabolite from the slime mold Fuligo cinerea (Schwein.) Morgan. Eur J Org Chem 13:2708-2714

Salehghamari E, Soleimani M, Tafakori V (2015) Antibacterial activity of some actinomycetes isolated from soils of Alborz province, Iran. Prog Biol Sci 5(2):159-167

Sasaki H, Kubohara Y, Ishigaki H, Takahashi K, Eguchi Y, Sugawara A, Oshima Y, Kikuchi H (2020) Two new terpenes isolated from Dictyostelium cellular slime molds. Molecules 25:2895

Sawada T, Aono M, Asakawa S, Ito A, Awano K (2000) Structure determination and total synthesis of a novel antibacterial substance, AB0022A, produced by a cellular Slime Mold. J Antibiotics 53(9):959-966

Schroeder HR, Mallette MF (1973) Isolation and purification of antibiotic material from Physarum gyrosum. Antimicrob Agents Chemother 4(2):160-166

Sevindik M, Baba H, Bal C, Colak O, Akgul H (2018) Antioxidant, oxidant and antimicrobial capacities of Physarum album (Bull.) Chevall. JBMOA 6(6):317-320

Simpkin VL, Renwick MJ, Kelly R, Mossialos E (2017) Incentivising innovation in antibiotic drug discovery and development: progress, challenges and next steps. J Antibiot 70:1087-1096

Sobels JC (1950) Nutrition de quelque myxomycetes en cultures et associees et leurs proprietes antibiotiques. Antonie Van Leeuwenhoek J Microbiol Serol 16:123-243

Steglich W (1989) Slime molds (myxomycetes) as a source of new biologically active metabolites. Pure Appl Chem 61:281-288

Steglich W, Steffan B, Kopanski L, Eckhardt G (1980) Indole pigments from the fruiting bodies of the slime mold Arcyria denudata. Angew Chem Int Ed Engl 19(6):459-460

Tafakori V and Nasiri N (2018) Effects of methanolic extrac of Calceolaria Herbeohybrida on microorganisms. In: Iran's 19th International congress of microbiology. 4-6 September.

Wang Q, Li Y, Liu P (2017) Physiology and biochemistry of Myxomycetes. In: Myxomycetes: biology, systematics, biogeography, and ecology. Elsevier Inc 193.

Willey JM, Sherwood LM, Woolverton CJ (2014) Prescott's microbiology, 9th edn. McGraw-Hill, New York

Wohlleben W, Mast Y, Stegmann E, Ziemert N (2016) Antibiotic drug discovery. Microb Biotechnol 9(5):541-548

Wright GD (2014) Something old, something new: revisiting natural products in antibiotic drug discovery. Can J Microbiol 60:147-154

\section{Publisher's Note}

Springer Nature remains neutral with regard to jurisdictional claims in published maps and institutional affiliations. 